\title{
CULTURABLE FUNGAL DIVERSITY OF SHRIMP LITOPENAEUS VANNAMEI BOONE FROM BREEDING FARMS IN BRAZIL
}

\section{Lidiane Roberta Cruz da Silva ${ }^{1}$; Odacy Camilo de Souza ${ }^{1}$; Maria José dos Santos Fernandes ${ }^{1}$; Débora Maria Massa Lima $^{1}$; Rosalie Reed Rodrigues Coelho ${ }^{2}$; Cristina Maria Souza-Motta ${ }^{1}$}

${ }^{1}$ Departamento de Micologia, Universidade Federal de Pernambuco, Recife, PE, Brasil; ${ }^{2}$ Departamento de Microbiologia Geral, Instituto de Microbiologia, Universidade Federal do Rio de Janeiro, RJ, Brasil.

Submitted: July 01, 2010; Approved: August 26, 2010.

\begin{abstract}
Litopenaeus vannamei, which is the most common shrimp species cultivated in the northeast of Brazil, is very susceptible to microbial diseases, and this consequently affects productivity. There are reports of bacteria, viruses and protozoa in these shrimp, but not fungi. This study aims to isolate and identify fungi present in shrimp Litopenaeus vannamei, and in their nursery waters, at two breeding farms in Brazil. The pathogenic potential of the isolates was assessed through the qualitative detection of proteases and aflatoxin B production. The 146 isolated fungi comprised 46 species. Aspergillus, Penicillium and Furarium were the three most relevant genera and Aspergillus flavus was the predominant species with a total of 33 isolates. Most of the isolated species are known as potentially pathogenic to humans and other animals. Eighteen isolates of A. flavus and two of A. parasiticus were able to produce aflatoxin B and 33 out of the 46 species produced protease, indicating that these fungi may also become pathogenic to shrimp and their consumers.
\end{abstract}

Key words: shrimp, fungi, water, protease, aflatoxin B.

\section{INTRODUCTION}

Shrimp grown in captivity are very susceptible to diseases caused by microorganisms, and this dramatically affects productivity. Penaideae is a common shrimp family used in nurseries, and in northeastern Brazil, Litopenaeus vannamei (Boone) is the most cultivated species (8). Studies investigating the agents that affect this invertebrate are rare and only a few viruses, bacteria and protozoa are known to cause disease in these crustacea (32). No articles dealing with the presence of fungi in healthy cultivated Litopenaeus vannamei shrimp have been found in literature. Among the various enzyme groups produced by fungi, proteinases are a class with an important role in physiological and biotechnological processes (16). Some fungi secrete proteinases primarily to provide nutrients to the cells, however in pathogenic fungi these enzymes facilitate the adhesion and invasion in host tissue, acquiring a significant role in the destruction of cell membranes, which are composed, mainly, of proteins and lipids (15). Here, in particular, they may also act on shrimp carapace, which consists primarily of chitin, proteins and lipids (8).

Some species of the Aspergillus genus, especially $A$. 
flavus and A. parasiticus, can produce aflatoxins, mycotoxins derived from their secondary metabolism, which can contaminate grains, especially corn, peanut and wheat $(5,38)$. There are several types of aflatoxin, but aflatoxin B has the highest toxicity (17).

On most farms the shrimp are fed with artificial diet or artificial feed, which is mainly composed of corn grains and ground wheat with added proteins, vitamins and salts (27). However, in a farm in northeastern Brazil, shrimp are not fed with artificial feed but are fed with natural resources such as algae and small crustaceans, reproducing the natural habitat of these animals (10), and in this case the diet is called organic feed.

This study aims to isolate and identify culturable fungi in Litopenaeus vannamei (Boone) shrimp and in the nursery waters of two farms in northeast Brazil, one with the artificial feeding and the other with an organic feeding system. Furthermore, we screened the ability of the isolated fungi for proteolytic activity, and in a preliminary test, we detected the production of aflatoxin by some isolated strains.

\section{MATERIALS AND METHODS}

\section{Collection of shrimp and nursery water samples}

Adult shrimp showing the characteristics of the species and without external injuries were collected from nurseries. Water samples were collected from both adult and juvenile shrimp nurseries. Two breeding farms were chosen for this study, one which uses the artificial feeding system (Farm I) and other which uses the organic feeding system (Farm II). Both farms are located in Rio Grande do Norte, Brazil. Six shrimp samples and 36 water samples from both farms were collected in previously sterilized containers, transported to the laboratory, and processed on the same day.

\section{Isolation of fungi from shrimp and nursery water}

The fungal isolation from shrimp surfaces was based on the method described by Lacaz et al. (23). Twenty five grams of whole shrimp were weighed and suspended in $225 \mathrm{ml}$ of sterile distilled water. After hand shake rotations (two minutes) $0.1 \mathrm{ml}$ of the suspension was seeded in triplicate on the surface of Sabouraud agar medium plus chloramphenicol $(50 \mathrm{mg} / \mathrm{L})$, contained in Petri dishes. Fungi from nursery waters were isolated based on on the method described by Ali-Shtayeh et al.(2), by seeding one $\mathrm{ml}$ of each water sample, in triplicate, on the surface of the same medium. In both cases the plates were incubated at $28^{\circ} \mathrm{C} \pm 2^{\circ} \mathrm{C}$ until fungal growth, approximately 10 days. Then, fragments of fungal colonies were transferred, separately, to the same medium and incubated under the same conditions. After confirmation of purity, fungi were transferred to specific media for species-level identification.

\section{Identification of fungi}

For identification of the isolated fungi Czapeck-agar, potato-dextrose-agar (PDA) and malt extract-agar (23) were used. Macroscopic (colony color, appearance and size) and microscopic (somatic and reproductive microstructures) characteristics were observed in accordance with specific literature $(3,9,12,13,14,18,22,24,30,31,33,34,35)$.

The Aspergillus genus was studied using Aspergillus Differential Medium (ADM) (tryptone $15 \mathrm{~g}$, yeast extract $10 \mathrm{~g}$, ferric citrate $5 \mathrm{~g}$, agar $16 \mathrm{~g}$ ) (6), which differentiates species of the flavus group. The cultures were incubated for 72 hours at $28^{\circ} \mathrm{C} \pm 2^{\circ} \mathrm{C}$, in the dark, so the presence of yellow-orange to yellow-olive pigmentation on the back of the colony could confirm the isolates as belonging to the flavus group.

\section{Detection of the proteolytic activity}

Fragments of each fungal culture were transferred to the center of casein medium (skimmed milk $50 \mathrm{~g}$, agar $10 \mathrm{~g}$ and distilled water $1000 \mathrm{ml}$ ), contained in Petri dishes, and incubated at $28^{\circ} \mathrm{C} \pm 2{ }^{\circ} \mathrm{C}$ for 10 days. Proteolytic activity was detected by the formation of a transparent zone around the growth. To distinguish between casein hydrolysis and 
clarification of the medium due to acids or alkaline metabolites present in milk, an acidified solution of mercury chloride (mercury chloride $12 \mathrm{~g}, 16 \mathrm{ml}$ concentrated hydrochloric acid and distilled water $100 \mathrm{ml}$ ) was poured into the plates. After 10 minutes, the reduction of the transparent zone indicated that casein was not digested (23).

\section{Detection of aflatoxin $B$ production}

An agar plug (3 $\mathrm{mm}$ in diameter) obtained from the culture growth of each fungus in ADM medium (2-3 days, $28^{\circ} \mathrm{C} \pm 2^{\circ} \mathrm{C}$ ) was center inoculated in Coconut Agar Medium (CAM) ("Socôco" Coconut Milk 200 ml, agar 16.0 g, distilled water $1000 \mathrm{ml}, \mathrm{pH} 6.9$ ) (25) and incubated for 6-7 days at $28^{\circ} \mathrm{C}$ $\pm 2^{\circ} \mathrm{C}$. The presence of aflatoxin $\mathrm{B}$ was detected by observing a blue to violet fluorescent zone on the back of the growth when subjected to UV light $(365 \mathrm{~nm})$ in a dark chamber (Tecnal, model: TE-540).

\section{RESULTS}

One hundred and forty six fungal isolates were obtained from adult shrimp (51 isolates) and nursery water (95 isolates), comprising 20 genera and 46 species (Tables 1, 2 and 3). Aspergillus (Table 2) and Penicillium (Table 3) were the most common genera, comprising 12 and 14 species, respectively. In addition, three different species of the Fusarium genus were also isolated (Table 3). These three genera comprised $73 \%$ of total isolates. All other 17 genera were isolated as a single species (Table 1).

Aspergillus flavus was the predominant species and was present in all samples, i.e., in adult shrimp and in nursery waters on both farms, comprising 33 isolates (Table 2). Three other species were also relevant: Aspergillus parasiticus, with seven isolates, and Aspergillus fumigatus and Penicillium griseofulvium, with six isolates each. Species with four $(A$. niger, A. ochareceus, and P. waksmanii) three (A. terreus, $P$. aurantiogriseum, $P$. citrinum, $P$. commune and $P$. corylophilum) and two isolates (A. japonicus, A. oryzae, A. sydowii and P. finiculosum) were also obtained (Tables 2 and 3).

When casein was used as substrate, proteinase was detected in 33 of the 46 isolated species, comprising $72 \%$ of proteolytic strains (Tables 1, 2 and 3). Considering the 26 most prevalent species, belonging to the genera Aspergillus and Penicillium, only A. fumigatus, A. japonicus and $P$. simplicissimum were not capable of producing proteinase under these conditions (Table 2 and 3). The three Fusarium species isolated didn't show any hydrolysis zone in the presence of casein either (Table 3).

The 33 Aspergillus flavus and seven A. parasiticus isolates were tested for their ability to produce aflatoxin B. Twenty were positive, 18 (55\%) belonging to A. flavus and 2 (28\%) to A. parasiticus (Table 4). It is worth noting that only one isolate, out of the 18 Aspergillus flavus obtained from Farm I, which uses artificial feed, did not produced aflatoxin. Furthermore, the 15 Aspergillus flavus isolates obtained from shrimp and/or nursery water from the farm that uses organic feed (Farm II) showed no toxin production. The same trend occurred with $A$. parasiticus, although the number of tested isolates was much lower: the two isolates obtained from Farm I nursery waters showed aflatoxin production, while all five isolates obtained from Farm II nursery waters or shrimp did not show any aflatoxin production.

After identification and detection of proteinase production a representative of each isolated species, which retained its sporulation ability, was preserved in the URM Micoteca Culture Collection of the Federal University of Pernambuco, Recife-PE, Brazil. 
Table 1. Occurrence of different fungi genera isolated from shrimp and nursery waters from two farms, one with an artificial feeding system (I) and the other with an organic feeding system (II) and their proteolytic activity. (*) In parentheses the sole isolated species of the genus.

\begin{tabular}{|c|c|c|c|c|c|}
\hline \multirow[t]{2}{*}{ Genera } & \multicolumn{2}{|c|}{$\begin{array}{c}\text { Farm I } \\
\text { (artificial feeding) }\end{array}$} & \multicolumn{2}{|c|}{$\begin{array}{c}\text { Farm II } \\
\text { (organic feeding) }\end{array}$} & \multirow{2}{*}{$\begin{array}{l}\text { Proteolytic } \\
\text { activity }\end{array}$} \\
\hline & Shrimp & Nursery water & Shrimp & Nursery Water & \\
\hline $\begin{array}{l}\text { Absidia } \\
\text { (A. blakesleeana Lendn.)* }\end{array}$ & - & 1 & - & 1 & + \\
\hline $\begin{array}{l}\text { Acremonium } \\
\text { (A. fusidioides(Nicot) W. Gams ) }\end{array}$ & - & 1 & - & - & - \\
\hline $\begin{array}{l}\text { Alternaria } \\
\text { (A. alternata }(\text { Fr.) Keissler }\end{array}$ & - & - & - & 1 & - \\
\hline Aspergillus & 9 & 24 & 8 & 25 & A \\
\hline $\begin{array}{l}\text { Aureobasidium } \\
\text { (A. pullulans var. pullulans) }\end{array}$ & - & 2 & 2 & - & + \\
\hline Cladosporium (C.cladosporioides (Fres) de Vries & - & 2 & - & 4 & + \\
\hline $\begin{array}{l}\text { Cunninghamella } \\
\text { (C. elegans Lendner) }\end{array}$ & - & - & - & 1 & + \\
\hline $\begin{array}{l}\text { Drechslera } \\
\text { (D. biseptata (Sacc \& Roum) Richardson \& } \\
\text { Frazer) }\end{array}$ & - & - & 1 & - & - \\
\hline $\begin{array}{l}\text { Eurotium } \\
\text { (E. chevaliere L. Mangin) }\end{array}$ & 1 & 3 & 1 & 3 & - \\
\hline Fusarium & 4 & 4 & 1 & - & $\mathrm{A}$ \\
\hline $\begin{array}{l}\text { Mucor } \\
\text { (M. hiemalis Schipper) }\end{array}$ & - & - & 1 & - & + \\
\hline $\begin{array}{l}\text { Paecilomyces } \\
(P . \text { variotii Bain.) }\end{array}$ & 2 & 1 & 1 & - & + \\
\hline Pencicillium & 6 & 9 & 7 & 10 & A \\
\hline $\begin{array}{l}\text { Pestalotiopsis } \\
\text { (P. guepini (Desm.) Steyaert) }\end{array}$ & 1 & - & 1 & - & - \\
\hline $\begin{array}{l}\text { Phaeoanellomyces } \\
\text { (P. werneckii (Horta) McGinnis et Schell) }\end{array}$ & 1 & 1 & - & - & + \\
\hline $\begin{array}{l}\text { Phialophora } \\
(P . \text { radicicola } \text { Cain) }\end{array}$ & - & 1 & - & 1 & - \\
\hline $\begin{array}{l}\text { Rhinocladiella } \\
\text { (R. aquaspersa Shell) }\end{array}$ & - & - & 1 & - & + \\
\hline $\begin{array}{l}\text { Rhizopus } \\
\text { (R. oryzae Went. \& Prinsen Geere) }\end{array}$ & - & - & 1 & - & + \\
\hline $\begin{array}{l}\text { Rhodotorula } \\
\text { (R. glutinis (Fr.) Harrison) }\end{array}$ & 1 & - & - & - & + \\
\hline $\begin{array}{l}\text { Syncephalastrum } \\
\text { (S. racemosum(Cohn.)Scroet. ) }\end{array}$ & 1 & - & - & - & + \\
\hline
\end{tabular}


Table 2. Occurrence of different species of Aspergillus isolated from shrimps and nursery water from farms with artificial feeding system (I) and organic feeding system (II) and its proteolytic activity.

\begin{tabular}{|c|c|c|c|c|c|}
\hline \multirow[b]{2}{*}{ Genera } & \multicolumn{2}{|c|}{$\begin{array}{c}\text { Farm I } \\
\text { (artificial feeding) }\end{array}$} & \multicolumn{2}{|c|}{$\begin{array}{c}\text { Farm II } \\
\text { (organic feeding) }\end{array}$} & \multirow{2}{*}{$\begin{array}{c}\text { Proteolytic } \\
\text { activity }\end{array}$} \\
\hline & Shrimp & Nursery water & Shrimp & Nursery water & \\
\hline Aspergillus caespitosus Raper \& Thom & - & - & - & 1 & - \\
\hline A. flavipes (Bain. and Sart.) Thom & - & - & 1 & - & + \\
\hline A. flavus Link & 6 & 13 & 3 & 11 & + \\
\hline A. fumigatus Fresenius & - & 3 & - & 3 & - \\
\hline A. japonicus Saito & - & 1 & - & 1 & - \\
\hline A. niger $\mathrm{V}$. Thieg. & 1 & 1 & - & 2 & + \\
\hline A. niveus Blochwitz & - & & - & 1 & + \\
\hline A. ochraceus Wilhelm & - & 2 & 1 & 1 & + \\
\hline A. oryzae (Ahlb.) Cohn & 1 & 1 & - & - & + \\
\hline A. parasiticus Speare & - & 2 & 2 & 3 & + \\
\hline A. sydowii (Bain. \& Start.)Thom and Church & - & 1 & - & 1 & + \\
\hline A. terreus Thom & 1 & - & 1 & 1 & + \\
\hline
\end{tabular}

Table 3. Occurrence of different species of Penicillium and Fusarium isolated from shrimp and nursery waters from two farms, one with an artificial feeding system (I) and the other with an organic feeding system (II) and their proteolytic activity

\begin{tabular}{|c|c|c|c|c|c|}
\hline \multirow[t]{2}{*}{ Genera } & \multicolumn{2}{|c|}{$\begin{array}{c}\text { Farm I } \\
\text { (artificial feeding) }\end{array}$} & \multicolumn{2}{|c|}{$\begin{array}{c}\text { Farm II } \\
\text { (organic feeding) }\end{array}$} & \multirow{2}{*}{$\begin{array}{l}\text { Proteolytic } \\
\text { activity }\end{array}$} \\
\hline & Adult shrimp & Nursery Water & Adult shrimp & Nursery water & \\
\hline $\begin{array}{l}\text { Penicillium aurantiogriseum } \\
\text { Dierckx }\end{array}$ & 1 & 1 & - & 1 & + \\
\hline P. citrinum Thom & - & - & 3 & - & + \\
\hline P. commune Thom & - & - & 2 & 1 & + \\
\hline P. chrysogenum Thom & - & - & - & 1 & + \\
\hline P. corylophilum Dierck. & 1 & - & 1 & 1 & + \\
\hline P. decumbens Thom & - & - & - & 1 & + \\
\hline P. funiculosum Thom & 1 & 1 & - & - & + \\
\hline P. griseofulvum Dierck. & - & 2 & 1 & 4 & + \\
\hline P. implicatum Biourge & - & 1 & - & - & + \\
\hline P. janthinellum Biourge & - & 1 & - & - & + \\
\hline P. lividum Westling & - & 1 & - & - & + \\
\hline P. pinophilum Hedgcock & - & - & - & 1 & + \\
\hline P. simplicissimum (Oudemans) & - & 1 & - & - & - \\
\hline P. waksmanii Zaleski & 3 & 1 & - & - & + \\
\hline Fusarium lateritium Nees & 3 & 2 & 1 & - & - \\
\hline F. moniliforme Wr. \& Rg. & - & 2 & - & - & - \\
\hline F. oxysporum (Smith) Wr. \& Rg. & 1 & - & - & - & - \\
\hline
\end{tabular}


Table 4. Detection of aflatoxin production by Aspergillus flavus and Aspergillus parasiticus isolated from adult shrimp and nursery waters from two farms, one with an artificial feeding system (I) and the other with an organic feeding system (II).

\begin{tabular}{lcccc}
\multicolumn{1}{c}{ Species } & Substrate & Feeding System & \multicolumn{2}{c}{ Detection of aflatoxin production } \\
\cline { 3 - 5 } Aspergillus flavus & $\begin{array}{c}\text { adult } \\
\text { shrimp } \\
\text { nursery water }\end{array}$ & I & 6 & 0 \\
Aspergillus flavus & adult shrimp & II & 12 & 1 \\
Aspergillus flavus & nursery water & II & 0 & 3 \\
Aspergillus parasiticus & nursery water & I & 0 & 0 \\
Aspergillus parasiticus & adult & II & 2 & 2 \\
Aspergillus parasiticus & nursery water & II & 0 & 3 \\
\hline
\end{tabular}

\section{DISCUSSION}

In the present study 20 genera and 46 species of culturable fungi were identified in Litopenaeus vannamei shrimp and their cultivation waters at two farms in Brazil. The three most relevant genera were Aspergillus, Penicillium and Furarium. There are several reports on the diversity of viruses (37), bacteria $(11,28)$ and protozoa (20) that affect Litopenaeus vannamei grown in nurseries, however papers dealing with the isolation of conidial fungi, Ascomycota in healthy shrimp of this species, or water used for their cultivation, have not been reported so far. As to other shrimp species, Colorni (7) reported a fungal infection in Penaeus semisulcatus, cultivated in Israel. The author observed a large lesion in the muscle of a specimen of the shrimp, from which the fungus Fusarium solani was isolated, and concluded that the handling of infected shrimp may represent risk to farmers. Also Khoa et al. (21) isolated Fusarium incarnatum from gill lesions of the black tiger shrimp Penaeus monodon, grown in Vietnam, and found these shrimp to present high mortality. In our study Fusarium species were also detected, but in healthy specimens $(F$. lateritium, F.oxysporum), or in adult nursery water $(F$. lateritium and $F$. moniliforme).

Most of the species isolated in the present research have been reported as mycoses agents in humans, causing otomycosis, keratitis, skin infections, lung infections and even systemic infections. These are opportunistic fungi, which affect only humans and other animals that have some type of immune suppression, or are immunocompromised (18). Three pathogens well known to man may be cited, Phaeoannellomyces werneckii, which causes Tinea nigra, Syncephalastrum racemosum, responsible for skin infection and Rhinocladiella aquaspersa, which is the etiologic agent of chromoblastomycosis $(18,23)$. Although many of the isolated species are potential pathogens, it must be stressed that these environmental isolates might miss the genes responsible for pathogenesis when in contact with the host.

Aspergillus flavus was the most prevalent specie, comprising $22 \%$ of all isolates. A. fumigatus, A. niger and A. terreus were also prevalent, and have been reported as agents 
of pulmonary aspergillosis. Furthermore, A. flavus is known as the most powerful fungal species able to produce aflatoxins, which are mycotoxins with carcinogenic potential (23). In this study all 18 isolates of A. flavus and two of A. parasiticus which produced aflatoxin B were isolated from the farm where shrimp are feed with artificial feed, in contrast to the isolates obtained from the farm with organic feeding system, where none of them were able to produce this mycotoxin. Although the number of the samples is small, and therefore a statistical study could not be performed, our results indicate that, possibly, the artificial feed in the nurseries potentiates aflatoxin B production by these fungi, contaminating the shrimp, and therefore impairing their production, and also transferring the toxin to the consumers. Bintvihok et al. (4) analyzed 150 samples of black tiger shrimp Penaeus monodon in Thailand, fed with feed contaminated with aflatoxin B, and concluded that this type of system may reduce production, causing economic losses.

In our study 33 out of the 46 isolated species were able to degrade casein, comprising $72 \%$ of proteolytic strains. This number may be higher, if one considers that different isolates of the same species can present different proteolytic characteristics. Although casein proteolysis is not a direct indication of pathogenesis to shrimp and their consumers, it is well known that proteinases are important enzymes for both, fungal growth and host tissue invasion (23). Also Horng-Der et $a l$. confirmed the pathogenic nature of this enzyme to trigger allergic processes when they analyzed the effects of the production of serine protease by Penicillium chrysogenum and Aspergillus fumigatus in mechanisms of allergic diseases in humans (19).

It is important to emphasize that this is the first report of the isolation of conidial fungi and Ascomycota in shrimp cultivation water, and that there are few reports of diseases in shrimp caused by fungi. Furthermore, as far as we know, there is no description in literature about the diversity of species of culturable fungi present in healthy cultivated shrimp

\section{Litopenaeus vannamei.}

So, in conclusion, the results of the present study demonstrate a significant diversity of culturable fungi. Most of the isolated species were obtained from adult shrimp artificially cultivated and from their nursery waters, and they presented aflatoxin production and proteolytic activity, suggesting that they may possibly be pathogens for both, the shrimp and the consumers.

\section{ACKNOWLEDGMENTS}

This work was supported by CNPq. The authors are grateful to Nogueira, E.B.S. and Torres, K.B. for technical support.

\section{REFERENCES}

1. Alexopoulos, C.J.; Mims, C.W.; Blackwell, M. (1996). Introductory mycology. John Wiley \& Sons, Inc, New York.

2. Ali-shtayed; Khaleel, T.K.M.; Jamous, R.M.F. (2003). Ecology of dermatophytes and other keratinophilic fungi in swimming pools and polluted and unpolluted streams. Mycopathologia. 156 (3), 51- 59.

3. Barnett, J.A.; Payne, R.W.; Yarrow, D. (2000). Yeasts characteristics and identification. Cambridge University Press, Spain.

4. Bintvihok, A.; Ponpornpisit, A.; Tangtrongpiros, J.; Panichkriangkrai, W.; Rattanapanee, R.; Doi, K.; Kumagai, S. (2003). Aflatoxin contamination in shrimp feed and effects of aflatoxin addition to feed on shrimp production. J. Food Prot, 66 (5), 882- 888.

5. Bok, J.W.; Keller, N.P.; Lae, A. (2004). A regulator of secondary metabolism in Aspergillus spp. Euk Cell. 3, 527- 535.

6. Bothast, R.J.; Fennel, D.I. (1974). A medium for rapid identification and enumeration of Aspergillus flavus and related organisms. Mycologia. 66, 365-369.

7. Calorni, A. (1989). Fusariosis in the shrimp Penaeus semisulcatus cultured in Israel. Mycophatologia. 108, 145- 147.

8. Campos, A.A.B.; Maia, E.P.; Costa, W.M.; Brito, L.O.; Oliveira, A. (2007). Descrição dos principais grupos fitoplanctônicos do afluente e efluente em fazenda de criação do camarão marinho Litopenaeus vannamei com sistema de recirculação parcial de água. B. Inst. Pesca. 33, $113-119$.

9. Carmichael, J.W.; Kendrick, W.B.; Conners, I.L.; Singler, L. (1980). Genera of Hyphomycetes. University of Alberta Press, Canadá. 
10. Chellapa, N.T.; Lima, A.K.A.; Câmara, F.R.A. (2007). Riqueza de microalgas em viveiros de cultivo orgânico de camarão em Tibau do Sul, Rio Grande do Norte. Rev. Bras. Bioc. 5 (2), 120- 122.

11. Cheng, W.; Wang, L.; Chen, J. (2005). Effect of water temperature on the immune response of with shrimp Litopenaeus vannamei to Vibrio alginolyticus. Aquaculture. 250, 592- 601.

12. Domsch, K. H.; Gams, W.; Anderson, T. (1993). Compendium of soil fungi v. I. IHW - Verlag, San Francisco.

13. Ellis, M.B. (1971). Dematiaceous hyphomycetes. Commonwealth Mycological Institute, Kew.

14. Ellis, M.B. (1976). More dematiaceous Hyphomycetes. Commonwealth Mycological Institute, Kew.

15. Ghannom, M.A. (2000). Potential role of phospholipase in virulence and fungal pathogenesis. Clin. Microbiol. Rev. 13, 122- 143.

16. Gouka, R.J.; Punt, P.J.; van den Hondel, C.A.M.J.J. (1997). Efficient production of secreted proteins by Aspergillus progress, limitations and prospects. App. Microbiol. Biotechnol. 47, 1- 11.

17. Groopman, J.D.; Cain, L.G.; Kensler, T.W. (1992). Exposure in human populations: measurements and relationship to cancer. CRC Crit. Rev. Toxicol. 19, 113-145.

18. Hoog, G.S; Guarro, J.; Gene, J. (2000). Atlas of clinical fungi. Centraalbureua voor Schimmelcultures, 2nd Edition., Utrecht, The Netherlands.

19. Horng-Der, S.; Ming, F.T.; Ren-Bin, T.; Hong, C. (2007). Aspergillus and Penicillium allergens: focus on proteases. Curr. Allergy Asthma Rep. 7, 351- 356

20. Jiménez, R.; Barniol, L.; Machuca, M. (2002). Nematopsis marinus n. sp., a new septate gregarine from cultured penaeoid shrimp Litopenaeus vannamei (Boone), in Ecuador. Aquaculture res. 33 (4), 231- 240.

21. Khoa, L.V.; Hatai, K.; Aoki, T. (2004). Fusarium incarnatum isolated from black tiger shrimp, Penaeus monodon Fabricius, with black gill disease cultured in Vietnam. J. Fish. Disease. 27, 507- 515.

22. Klick, M.A. (2002). Identification of Common Aspergillus Species. Centraalbureau voor Schimmelcultures, Utrecht,. the Netherlands.

23. Lacaz, C.S.; Porto, E.; Martins, J.C; Heins-Vaccari, E.M.; Melo, N.T. (2002). Tratado de micologia médica. Sarvier, São Paulo.

24. Leslie, J.F.; Summerell, B.A. (2006). The Fusarium laboratory manual. Blackwell Publishing, Malden MA, USA.

25. Lin, M.T.; Dianese, J.C. (1976). A coconut-agar medium for rapid detection of aflatoxin production by Aspergillus spp. Phytopathology. 66, 1466- 1469 .

26. Mangiarotti, A.M.; Careta, G. (1984). Keratinophilic fungi isolated from a small pool. Mycopathologia. 85, 9- 11 .
27. Mendes, P.P.; Albuquerque, M.L.L.T.; Queiroz, D.M.; Santos, B.L.S.; Lima, A.C.; Lopes, Y.V.A. (2006). Aclimatação do camarão marinho Litopenaeus vannamei (Boone, 1931) à água doce com diferentes estratégias de alimentação e calagem. Acta Sci. Anim. Sci. 28 (1), 89- 95.

28. Moss, S.M.; LeaMaster, B.R.; Sweeney, J.N. (2007). Relative abundance and species composition of Gram-negative, aerobic bacteria associated with the gut of juvenile white shrimp Litopenaeus vannamei reared in oligotrophic well water and eutrophic nursery water. J. World Aquac. Soc. 31 (2), 225- 263

29. Pinheiro, W.C.; Filho, J.A.; Maracajá, P.B. (2007). Efeitos climáticos e físico-químicos sobre a biologia do Litopenaeus vannamei cultivado em viveiro. Rev. Verde. 2, 142- 150.

30. Pitt, J.I. (1988). A laboratory Guide to Common Penicillium Species. Commonwealth scientific and industrial research organization - Division of food processing, North Wales.

31. Pitt, J.I. (1991). A laboratory Guide to Common Penicillium Species. Commonwealth scientific and industrial research organization - Division of food processing, North Wales.

32. Pontes, C. S.; Arruda, M. F. (2005). Comportamento de Litopenaeus vannamei (Boone) (Crustacea, Decapoda, Penaeidae) em função da oferta do alimento artificial nas fases clara e escura do período de 24 horas. Rev. Bras. Zool. 22, 648- 652.

33. Raper, K.B.; Fennel, D.I. (1977). The genus Aspergillus. Robert \& Krieger, Florida.

34. Riddell, R.W. (1950). Permanent stained mycological preparation obtained by slide culture. Mycologia. 42, 265- 270.

35. Samson, R.A.; Frisvad, J.C. (2004). Penicillium subgenus Penicillium: new taxonomics schemes, mycotoxins and other extrolites. Stud. Mycol. 49, 1 - 266.

36. Shakeri, J.; Foster, H.A. (2006). Proteolytic activity and antibiotic production by Trichoderma harzianum in relation to pathogenicity to insects. Enz. Microb.Technol. 40 (4), 961- 968.

37. Vidal, O.M.; Granja, C.B.; Aranguren, F.; Brock, J.A.; Salazar, M. (2007). A profound effect of hyperthermia on survival of Litopenaeus vannamei juveniles infected with White Spot Syndrome Virus. J. World Aquac. Soc. 32 (4), 364-372.

38. Yu, J.; Cleveland, T.E.; Nierman, W.C.; Bennett, J.W. (2005). Aspergillus flavus genomics: gateway to human and animal health, food safety, and crop resistance to diseases. Rev. Iberoam. Micol. 22, 194202.

39. Zar, J.H. (1999). Biostatistical analysis. Prentice-Hall International, New Jersey. 